\title{
The Effects of Managerial Ownership on the Relationship between Intellectual Capital Performance and Firm Value
}

\author{
H. Noradiva, A. Parastou, and A. Azlina
}

\begin{abstract}
In knowledge-based economy, intellectual capital is the most important resources. Thus, investment in intellectual capital is crucial in order to increase firm performance and market value. This will contribute to economic growth of a country. This study is among the earliest study that examine the effect of managerial ownership on the relationship between intellectual capital performance and firm value. This study applied Pulic's Value Added Intellectual Coefficient method as the efficiency measure for measuring intellectual capital performance. The results showed the non-significant non-linear effect of managerial ownership on the relationship between intellectual capital performance and firm value.
\end{abstract}

Index Terms-Intellectual capital performance, firm value.

\section{INTRODUCTION}

In knowledge-based economy, Intellectual capital (IC) has become the pre-eminent economic resources. Hence, firms must have the ability to exploit the knowledge that is embedded in their firms, employees, suppliers and customers in order to compete and sustain. The knowledge that is embedded in firm's employees, suppliers, and customers has been term as IC [1], [2]. Previous studies shown that firm's efforts to invest and manage its IC will lead to relatively higher business performance [3], [4]. According to Cahill (2000) [5], 50\%-90\% of a firm's value is contributed by the efficient management of IC.

According to Ong, Yeoh and Teh [6] (2011), the investment in IC by many successful companies like Google and Microsoft is higher than the investment in its' physical and financial assets. Investment decision is a risky decision. Therefore, managers must be very cautious and vigilant when making investment decisions. There are many factors that contribute to the investment process decision. For example, it is said that if the manager is the owner of the firm, he will focus more on the long term value of the firm. Thus it is more likely to make investment decision that would increase firm's market value. So far, there are only a few empirical studies conducted to investigate the relationship on managerial ownership and IC and firm value [7]. In particular that is not much study that has attempted to examine the effect of managerial ownership on IC and firm value. The objective of this study is to investigate the effect of managerial ownership on the relationship between Intellectual Capital

Manuscript received January 9, 2014; revised March 15, 2015.

H. Noradiva and A. Azlina are with the National University of Malaysia, 43600 UKM, Selangor, Malaysia (tel.: +603-8921-5754; fax +603-8921-3162; e-mail: adibz@ukm.edu.my, azlinaahmad@ukm.edu.my).

A. Parastou is with the School of Accounting, National University of Malaysia, 43600 UKM, Selangor, Malaysia.
Performance(ICP) and firm value.

\section{LITERATURE REVIEW}

\section{A. Background of Study}

Much of the existing literature argues that the key feature of business environment in knowledge-based economy is the ascendency of knowledge embedded assets [4]. According to Stewart (2002) [8], in knowledge-based economy, IC is become important and the challenge to all firms is to produce and process its knowledge. IC is vital and it is part of the story of companies' wealth [8]. IC has become the most important factors of production and is the most powerful producers of wealth. Therefore, IC could be found in the competencies of employees, a firm's internal structure (patterns, models and administrative systems), and a firm's external structure (brands, reputation, relationship with customers and suppliers) [9], [8]. In short, there is a multi-facet description of IC proposed by intellectual capital theorists. However, most of the definition and framework of IC include human, customers, suppliers, and organizations elements [8].

Previous studies have shown that IC has significant impact on firm performance [7]. Therefore, investment in IC is crucial and intellectual capital performance (ICP) is an important indicator to evaluate firm's competitive advantage. The value added of a firm is attained through the efficiency of firm's IC development activity [10], [11]. A company's efforts to manage and develop its IC will lead to a relatively higher business performance [12].

Managers are expected to strongly influence on firm's investment in IC as they are better able to understand the value creation role of IC. Previous research found that managerial ownership could mitigate the problem of managerial myopia by aligning the interest of managers and shareholders [13].

\section{B. IC and Firm Value}

Previous studies found a positive relationship between IC and firm's performance [7], [27]. Norman et al., (2009) [7] argued that investment in IC is crucial because it contributes to company long term competitive advantage. Intellectual Capital Performance (ICP) is defined as the effectiveness of investment in resources for making values. Clarke et al., (2011) [14] showed that ICP has a positive effect on firm's ROA, ROE and employee productivity [15], [16].

Firm's market value is one of the indicators used to measure firm's performance. Its' provide information about firm's performance and can be used to predict firm's future performance. The market value of a firm is measured by 
applying the market value ratio. This ratio was widely used in the previous studies to measure firm's value [17], [11].

VAIC $^{\mathrm{TM}}$ (Value Added Intellectual Coefficient) is widely used to measure the impact of IC performance [9] Sveiby. This model was developed by Pulic in 1998. VAIC takes stakeholder perspective to measure the efficiency a firm uses its physical, financial and IC to enhance stakeholder value. VAIC index consist of the sum of three component ratios (human capital efficiency, structural capital efficiency and capital employed efficiency [18].

\section{Managerial Ownership and ICP and Firm Value}

Managerial ownership has been identified as an effective corporate governance mechanism as it helps align the interest of managers and shareholders [19]. This in turn can mitigate agency problem due to the separation of ownership and control and reduce agency costs. As equity owners, managers have the incentive to monitor firms carefully to ensure higher returns from their ownership [19]. Past studies have shown that high level of managerial ownership is associated with higher firm performance and firm value [20], [21]. Additionally managers with high level of ownership has been found to focus more on long term value of the firm and thus are more likely to make investment decisions that could increase long term value of the firm, such as investment in intellectual capital [7]. Anis [22] found that corporate governance mechanisms significantly moderate the influence of intellectual capital efficiency towards firm performance.

However studies by Mueller \& Spitz [23], [26] found the effect of managerial ownership to be non-linear. This means that when managerial ownership approaches a significantly higher level, the agency problem could be mostly mitigated due to the full alignment between the manager's and shareholder's interests [24], [25]; however beyond a certain level of managerial ownership, further increases in ownership might provide managers with adequate interest to pursue their own advantage without concern of its effect on firm value and the well-being of other shareholders.

\section{RESEARCH FRAMEWORK}

The conceptual framework was developed to examine the effect of managerial ownership on the relationship between ICP and firm value. According to agency theory, managerial ownership is effective in aligning the interest of managers and shareholders which in turn help reduce agency conflicts. In line with this view, this study argues that managers as owners of the firm are more likely to consider IC investment in order to increase the firm's market value. Based on Mueller \& Spitz [26], managerial ownership is expected to have a non-linear moderating effect on the relationship between ICP and firm value. This means that the effect is positive as managerial ownership increases but beyond a certain level of managerial ownership the positive effect is expected to invert. Fig. 1 depicts the research framework. As can be seen from Fig. 1, managerial ownership moderates the relationship between ICP and firm value. The moderation effect is expected to be non-linear. Firm value is measured based on market to book ratio, while ICP is measured based on VAIC developed by Pulic, (2000) [18]. VAIC comprises of Human Capital efficiency, Structural Capital efficiency and Capital Employed efficiency. Managerial ownership was measured based on the percentage of equity holdings by executive managers.

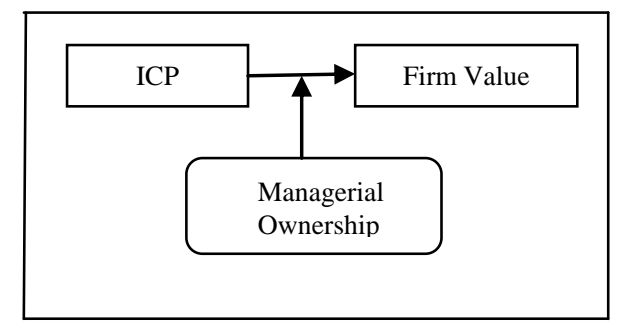

Fig. 1. Research framework.

\section{Methodology}

This study used panel data analysis to examine the effect of managerial ownership on the relationship between ICP and firm value. The sample was collected from companies listed on the ACE Market of Bursa Malaysia from 2009 to 2012. The final sample consists of 46 firms with data for four years, resulting in 184 firm year's observations. The following model was used to test the hypothesis:

$$
\begin{aligned}
M_{B} E_{\mathrm{it}}= & \alpha+\beta_{1} V^{\prime} I C_{\mathrm{it}+} \beta_{2} M O_{\mathrm{it}+} \beta_{3} \text { MOVAIC }_{\mathrm{it}}+\beta_{4} M O^{2}{ }_{\mathrm{it}}+ \\
& \beta_{5} \text { MOVAICMO }_{\mathrm{it}}+\beta_{5} \text { SIZE }_{\mathrm{it}}+\beta_{6} L E V E R A G E_{\mathrm{it}}+ \\
& \beta_{7} \text { PROFITABILITY }_{\mathrm{it}}+\epsilon_{\mathrm{it}}
\end{aligned}
$$

$M B E_{i}:$ Market value equity for firm $i$, measured based on market to book ratio.

$V A I C_{i}$ : Value Added intellectual coefficient for firm $i$. Comprises of HCE + SCE + CEE

MO: Managerial ownership for firm i, measured based on number of shares held by executive directors over total shares outstanding

Size $_{i}$ : Size for firm $i$, measured based on log total assets

Leverage $_{i:}$ Financial leverage for firm $i$, measured based on debt to total assets ratio.

Profirability: Profitability of firm $i$, measured based on return on assets (earnings before interest and tax divided by total assets)

The variable $\mathrm{MO}^{2}$ is derived by squaring MO to tests the non-linear effect managerial ownership. Regressions were also carried out on each component of VAIC (HCE, SCE and CEE).

\section{A. Findings}

Table I provides the descriptive statistics of the original data. Based on Table I, the average score for VAIC, is 3.510, with a maximum score 6.140 and a minimum score of 1.893 . The VAIC score indicates the level efficiency achieved from the use of a firm's intellectual and physical capital. Comparing the three components of VAIC, it can be seen that the HCE component is the dominant contributor of ICP, with a mean of 2.523 , making up $72 \%(2.523 / 3.510)$ of total VAIC. This is followed by SCE with $16 \% \quad(0.565 / 3.510)$ contribution and CEE with $11 \%(0.421 / 3.510)$ contribution. The results suggest that HCE is the most important element in creating VAIC or ICP. Thus, in the context of this study, firms with higher HCE are most likely to have higher VAIC. The average score for the market value of equity to book value of equity (MBE) is 1.077. The MBE value which is 
greater than one shows a surplus of equity value compared to book value in the market place. According to Edvinsson and Malone (1997)[26], surplus of market value over book value of equity can be associated with intangible assets or intellectual capital. The level of managerial ownership (MO) ranges from $11 \%$ to $80 \%$ with an average of $43 \%$, indicating a strong presence of owner-manager in sample firms. The mean for the control variables are 4.620 for firm size, 0.040 for leverage and 0.090 for ROA. The logarithm transformation was employed to the data to address the issue of data normality. Prior to testing of moderating effect, the transformed data were centered to address the issue of multicollinearity.

TABLE 1: DESCRIPTIVE STATISTICS OF ORIGINAL DATA

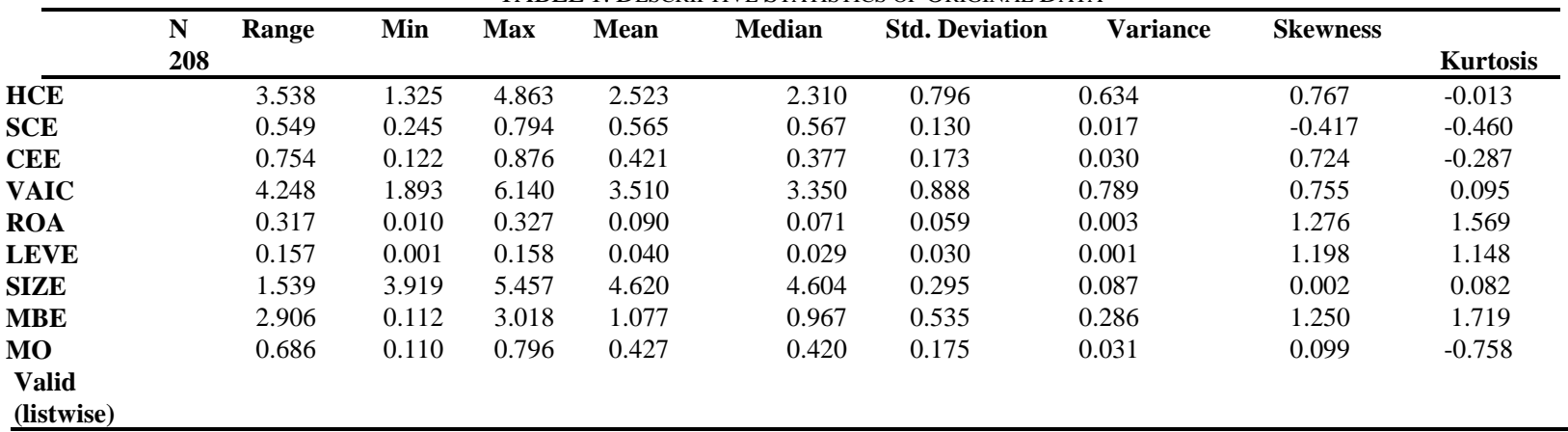

$\mathrm{HCE}$ is human capital efficiency that is value added (VA) over human capital (HC).VA is [operating profit + employee cost + depreciation + amortization]. HC is total salaries and wages. SCE is structural capital efficiency and calculates through [structural capital (SC) /VA). SC is [VA-HC]. CEE shows Capital employed efficiency and is VA over book value of the net assets. VAIC is value added intellectual coefficient and VAIC is HCE+ SCE+ CEE. ROA is earning before interest and tax over total assets. Leve is financial leverage and it is total debt over total assets. Size is the $\log ^{10}$ of total assets. MBE is the ratio of the market value of equity to book value of equity. MO is managerial ownership that is the percentage of shares held by executive and non-executive managers over shares outstanding.

TABLE II: SUMMARY REGRESSION RESULTS OF DIRECT ASSOCIATION BETWEEN VAIC AND MBE

\begin{tabular}{|c|c|c|c|c|c|c|c|c|}
\hline Model/IV & \multicolumn{2}{|c|}{ Model/LOGVAIC } & \multicolumn{2}{|c|}{ Model/LOGHCE } & \multicolumn{2}{|c|}{ Model/LOGSCE } & \multicolumn{2}{|c|}{ Model/LOGCEE } \\
\hline Variable & Coefficient & t- Statistic & Coefficient & t-Statistic & Coefficient & t-Statistic & Coefficient & t-Statistic \\
\hline IV & $0.414 * *$ & 2.430 & $0.368 * *$ & 2.519 & $0.426 * *$ & 2.469 & 0.042 & 0.284 \\
\hline LOGLEVE & $-0.109^{* *}$ & --2.078 & $-0.110 * *$ & -2.108 & $-0.110 * *$ & -2.120 & -0.073 & -1.417 \\
\hline LOGROA & 0.035 & 0.648 & 0.038 & 0.705 & 0.050 & 0.964 & 0.082 & 1.524 \\
\hline SIZE & $-0.385 * * *$ & -3.560 & $-0.393 * * *$ & -3.619 & $-0.357 * * *$ & -3.450 & $-0.283 * * *$ & -2.708 \\
\hline Adjusted R-squared & 0.647 & & 0.648 & & 0.648 & & 0.631 & \\
\hline F-statistic & 7.473 & & 7.506 & & 7.492 & & 7.034 & \\
\hline Prob(F-statistic) & 0.000 & & 0.000 & & 0.000 & & 0.000 & \\
\hline Durbin-Watson stat & 2.329 & & 2.344 & & 2.398 & & 2.178 & \\
\hline
\end{tabular}

***Significant at the 0.01 level. ** Significant at the 0.05 level. * Significant at the 0.10 level. IV is independent variable. Dependent Variable: LOGMBE.

\begin{tabular}{|c|c|c|c|c|c|c|c|c|}
\hline \multirow{2}{*}{$\begin{array}{l}\text { Model/IV } \\
\text { Variable }\end{array}$} & \multicolumn{2}{|c|}{ Model2/LOGVAIC } & \multicolumn{2}{|c|}{ Model2a/LOGHCE } & \multicolumn{2}{|c|}{ Model2b/LOGSCE } & \multicolumn{2}{|c|}{ Model2C/LOGCEE } \\
\hline & Coefficient & t-Statistic & Coefficient & t-Statistic & Coefficient & t-Statistic & Coefficient & t-Statistic \\
\hline CLLEVE & $-0.105 * *$ & -2.064 & $-0.105 * *$ & -2.080 & $-0.097 *$ & -1.907 & -0.075 & -1.552 \\
\hline CLROA & 0.047 & 0.885 & 0.054 & 1.036 & 0.074 & 1.419 & $0.089 *$ & 1.728 \\
\hline CSIZE & $-0.363 * * *$ & -3.395 & $-0.367 * * *$ & -3.457 & $-0.312 * * *$ & -3.059 & $-0.218^{* *}$ & -2.165 \\
\hline CMO & $-0.373^{* * *}$ & -2.838 & $-0.352 * * *$ & -2.685 & $-0.363 * * *$ & -2.693 & $-0.334^{* * *}$ & -2.650 \\
\hline CMO2 & -0.099 & -0.132 & -0.348 & -0.467 & -0.428 & -0.585 & 0.015 & 0.024 \\
\hline CIV & $0.511 * *$ & 2.580 & $0.466^{* * * *}$ & 2.826 & $0.453 * *$ & 2.463 & 0.045 & 0.331 \\
\hline CMO*CIV & 0.345 & 0.304 & 0.802 & 0.839 & 1.137 & 0.925 & $-1.894 * *$ & -2.425 \\
\hline CMO2*CIV & -2.786 & -0.478 & -4.183 & -0.881 & -4.824 & -0.846 & 0.397 & 0.126 \\
\hline Adjusted R-squared & 0.664 & & 0.666 & & 0.662 & & 0.666 & \\
\hline F-statistic & 7.464 & & 7.544 & & 7.407 & & 7.535 & \\
\hline Prob(F-statistic) & 0.000 & & 0.000 & & 0.000 & & 0.000 & \\
\hline Durbin-Watson stat & 2.452 & & 2.486 & & 2.500 & & 2.303 & \\
\hline
\end{tabular}

*** Significant at the 0.01 level. ** Significant at the 0.05 level. * Significant at the 0.10 level. IV is independent variable. Dependent Variable: LOGMBE.CLLEVE is centered LLEVE and computes by LLEVE minus its average. LLEVE isthe logarithm of financial leverage and computes by of total debt over total assets.CLROA is centered LROA and computes by LLEVE minus its average. CSIZE is centered SIZE and computes by SIZE minus its average. Size is the of total assets. $\mathrm{CMO}$ is centered MO and computes by MO minus its average.CMO2 is centered MO2 and computes by MO2 minus its average. MO2 is MO*MO.CLOGVAIC is centered LOGVAIC and computes by LOGVAIC minus its average. CLOGHCE is centered LOGHCE and computes by LOGHCE minus its average.CLOGSCE is centered LOGSCE and computes by LOGSCE minus its average. CLOGCCE is centered LOGCCE and computes by LOGCCE minus its average. CMO* CLOGVAIC is multiply of CMO and CLOGVAIC. CMO *CLOGHCE is multiply of CMO and CLOGHCE. CMO* CLOGSCE is multiply of CMO and CLOGSCE. CMO2*CLOGVAIC is multiply ofCMO2 and CLOGVAIC.CMO2*CLOGHCE is multiply of CMO2 and CLOGHCE. CMO2*CLOGSCE is multiply of CMO2 and CLOGSCE. 
The choice of methods between PLS and FEM was determined based on the Redundant test; while the Hausman test was used to determine the choice between fixed or random effect models. The Redundant fixed effect-likelihood ratio test reject the use of the pooled OLS model in lieu of the fixed effect model, while the Hausman test rejects the use of random effect model and indicate the use of fixed effect for both cross-section and period in all models.

Table II and Table III provides summary of the regression results. Table II provides a summary of the regression that test the direct association between VAIC as a measure of ICP and $\mathrm{MBE}$ as a measure of firm value. This study also test the individual components of VAIC. Table III provides a summary of the regression that tests the moderating effect of managerial ownership. As can be seen from Table II, the regression of VAIC on MBE shows a positively significant association. This means that improved intellectual capital performance would lead to higher market value of the firm. Similar results were obtained for the human capital efficiency (HCE) component and the structural capital efficiency (SCE) component but not for the capital employed efficiency (CEE) component. This indicates that investors place greater value on companies with higher intellectual capital.

However, the results in Table III show that managerial ownership does not moderate the relationship between ICP and firm value. The finding does not meet the expectation of this study. As discussed earlier, managerial ownership range from $11 \%-80 \%$, with an average of $43 \%$. This high level of managerial ownership may induce the entrenchment effect instead of the alignment effect of managerial ownership [7]. The insignificant effect of managerial ownership also suggests that risk aversion and managerial myopia may influence managerial decision on intellectual capital investment which may subsequently affect intellectual and firm value. Managerial myopia which indicates focus on short term performance may cause managers to prefer investments in tangible assets rather than intellectual capital, because tangible assets are easier to monitor and control as well easier to justify. Moreover, tangible assets are associated with lower uncertainty and risk, which contribute to strengthening the position of managers.

\section{CONCLUSION}

This study provides evidence of the positive effect of ICP on firm value. However, the result found a non-significant effect of managerial ownership on the relationship between ICP and firm value. It is suspected that issue of non-linearity of managerial ownership maybe a contributing factor. Although this study takes into consideration the non-linear effect, by including in the regression the variable managerial ownership squared $\left(\mathrm{MO}^{2}\right)$, further deliberation is needed to determine the type of the non-linear effect of managerial ownership. Additionally, future research could investigate more in-depth in order to better understand the incentives to invest in IC. Furthermore, the sample only focused on ACE Market companies, which include newly and technology-based companies, therefore, the generalizability of the findings may be limited.

\section{REFERENCES}

[1] N. Bontis, "Intellectual capital: An explanatory study that develops measure and models," Management Decision, vol. 36, no.2, pp. 63-76, 1998.

[2] N. Brennan, "Reporting intellectual capital in annual reports: Evidence from Ireland," Accounting, Auditing and Accountability Journal, vol. 14, no. 4, pp. 423-436, 2001.

[3] M. S. Wang, "Intellectual capital and firm performance," in Proc. the Annual Conference on Innovations in Business \& Management, 2011, pp. 1-26.

[4] D. Madtinos, D. Chatzoudes, C. Tsairidis, and G. Theriou, "The impact of intellectual capital on firms' market value and financial performance," Journal of Intellectual Capital, vol. 12, no. 1, pp. 132-151, 2011

[5] D. Cahill, "Recognizing intellectual capital: Lesons to be learnt fro, human resources accounting," Seminar Series, Melbourne, Australia: School of Accounting and Law, RMIT.E, pp. 5-27, 2000.

[6] T. S. Ong, L. Y. Yeoh, and B. H. Teh, "Intellectual capital efficiency in Malaysia food and beverage industry," International Journal of Business and Behavioral Scienes, vol. 1, no. 1, pp. 16-31, 2011.

[7] N. M. Saleh, M. Ridhuan, and S. H. Mohamat, "Ownership structure and intellectual capital performance in Malaysia," Asian Academy of Management Journal of Accounting and Finance, vol. 5, no. 1, pp. 1-29, 2009.

[8] T. A. Stewart, The New Wealth of Knowledge: Intellectual Capital and the Twenty-First Century Organizations, London: Nicholas Brealey Publishing, 2002.

[9] K. E. Sveiby. (2010). Methods for measuring intangible assets. [Online].

Available: http://www.sveiby.com/articles/intangiblemethods.htm

[10] M. Mehri, M. S. Umar, P. Saeidi, R. K. Hekmat, and H. R. Rasekh, "Intellectual capital performance in Iranian pharmaceutical industry," Journal of Intellectual Capital, vol. 13, no. 1, pp. 138-158, 2012.

[11] M. S. Mousavi, K. Mousavi, A. Pourezza, and S. Ahmadi, "The effect of intellectual capital on market value added," Journal of Basic and Applied Scientific Research, vol. 2, no. 7, pp. 7214-7226, 2012.

[12] S. Harrison and H. P. Sullivan, "Profiting from intellectual capital: Learning from leading companies," Industrial and Commercial Training, vol. 32, no. 4, pp. 139-148, 2002.

[13] M. Singh and W. N. Davidson, "Agency costs, ownership structure and corporate governance mechanisms," Journal of Banking and Finance, vol. 27 , no. 5 , pp. 793-816, 2003

[14] M. Clarke, D. Seng, and R. H. Whiting, "Intellectual capital and firm performance in Australia," Journal of Intellectual Capital, vol. 12, no. 4, pp. 505-530, 2011.

[15] M. Alipour, "The effect of intellectual capital on firm performance: An investigation of Iran insurance companies," Measuring Business Excellence, vol. 16, no. 1, pp. 53-66, 2012.

[16] B. Banimahd, F. Mohammadrezaei, and M. Mohammadrezaei, "The impact of intellectual capital on profitability, productivity and market valuation: Evidence from Iranian High Knowledge-based industries," Journal of Basic and Applied Scientific Research, vol. 2, no. 5, pp. 4477-4484, 2012.

[17] B. Soedaryono, A. Murtanto, and A. Prihartini, "Effect intellectual capital to market value and financial performance of banking sector companies listed in Indonesia Stock Exchange," in Proc. the International Conference on Business and Management, 2012, pp. 89-106.

[18] A. Pulic, "VAIC ${ }^{\mathrm{TM}}$ an accounting tool for IC management," International Journal of Technology Management, vol. 20, no. 5, pp. 702-714, 2000.

[19] J. A. Brickley, R. C. Lease, and C. W. Smith, "Ownership structure and voting on antitakeover amendments," Journal of Financial Economics, vol. 20 , pp. 267-291, 1988.

[20] R. C. Hanson and M. H. Song, "Managerial ownership, board structure and the devision of gains in divestitures," Journal of Corporate Finance, vol. 6, no. 1, pp. 55-70, 2000.

[21] X. Li and S. T. Sun, "Managerial ownership and firm performance: Evidence from the 2003 Tax Cut," Workshop papers series, 2013.

[22] I. Anis, "Corporate governance-driven to intellectual capital and corporate performance," in Proc. the International Conference on Business, Economics and Accounting, Bangkok, 2013, pp. 1-17.

[23] M. H. Cho, "Ownership structure, investment and the corporate value: An empirical analysis," Journal of Financial Economics, vol. 47, no. 1, pp. 103-121, 1998.

[24] J. J. McConnell and H. Servaes, "Additional evidence on equity ownership and corporate value," Journal of Financial Economics, vol. 27, no. 2, pp. 595-612, 1990. 
[25] E. Mueller and A. Spitz, Managerial Ownership and Firm Performance in German Small and Medium-Sized Enterprises, London Centre for Economic Performance, London School of Economics and Political Science, 2002, pp. 1-36.

[26] L. Edvinsson and M. S. Malone, Intellectual capital: Realizing your company's true value by finding its hidden brainpower, New York: Harper Business, 1997.

[27] P. Puntillo, "Intellectual capital and business performance: Evidence from Italian banking industry," Journal of Corporate Finance, vol. 4 no. 12 , pp. $97-115,2009$

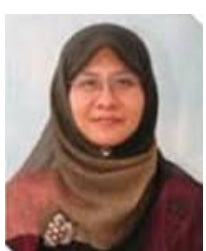

Noradiva Hamzah holds a bachelor of accounting from Universiti Kebangsaan Malaysia, an MA from New Castle Upon Tyne, UK and a Ph.D from University of Malaya. Her research areas of interest include intellectual capital reporting, intellectual capital management, knowledge management, and offshore accounting outsourcing.

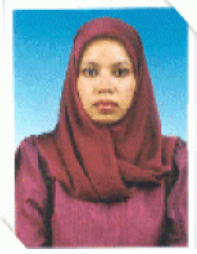

Azlina Ahmad holds a bachelor of accounting from Universiti Kebangsaan Malaysia, an MA from London School of Economics, UK and a Ph.D from University Kebangsaan Malaysia. Her research areas of interest include financial reporting and public sector reporting.

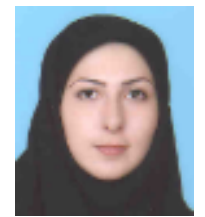

Parastou Aminiandih Kordi holds her first degree from a university in Iran and a master of accounting from University Kebangsaan Malaysia. 